\title{
Biocidal Potential of Plants Extracts Against Wood- Degrading Microbes and Their In-Vitro Application on Wood: As Promising Wood Natural Preservatives
}

\author{
Amina Ifthkar \\ Government College University, Faisalabad \\ Faiza Jabeen ( $\sim$ acancerian@hotmail.com ) \\ Government College University, Faisalabad

\section{Saima Mirza} \\ University of Education

\section{Afshan Abbas} \\ University of Education

\section{Tahira Younis} \\ Government College University, Faisalabad

\section{Muhammad Waseem} \\ Government College University, Faisalabad

\section{Mohnad Abdallah} \\ Qingdao Institute of Bioenergy and Bioprocess Technology Chinese Academy of Sciences, Qingdao, Shandong, China.
}

\section{Research Article}

Keywords: Medicinal plants, wood deterioration, wood degrading microbes, antimicrobial activity

Posted Date: January 18th, 2021

DOI: https://doi.org/10.21203/rs.3.rs-138701/v1

License: (c) (i) This work is licensed under a Creative Commons Attribution 4.0 International License. Read Full License 


\section{Abstract}

Background: Besides the increasing demand of wooden articles, there is a burning issue of microbial attack which affects the aesthetics of wood. Thus it is a current concern to protect the wooden articles from both fungal and bacterial attack by using toxin free preservatives.

Results: Powder of Calotropis procera (leaves), Curcuma zedoaria (rhizome) and Swertia chirata (whole plant) was extracted with solvents like methanol, ethanol and chloroform and then the qualitative phytochemical screening was carried out, which exhibited the presence of different secondary metabolites. These extracts were also evaluated against wood degrading microbes (Bacillus cereus, Escherichia coli, Pseudomonas aeruginosa, Aspergillus flavus and Aspergillus niger) isolated from decaying wood. Our study demonstrated that the ethanol extract of $S$. chairata showed highest bactericidal potential against E.coli $(19.0 \mathrm{~mm})$ and $A$. flavus $(19.33 \mathrm{~mm})$. This study also revealed that $S$. chirata exhibited strongest biocidal spectrum of action followed by $C$. procera and $C$. zedaira. It was observed that laminated veneer treated with ethanol extract of $S$. chirata showed strong bactericidal potential against E.coli $(82.67 \mathrm{~mm})$. On the other hand Syzygium cumini wood treated with ethanol extract of $C$. zedoaria exhibited high antibacterial potential against $P$. aeruginosa (58.0mm). The active plant extracts showed MIC's ranged from 3.6 to $6.0 \mathrm{mg} / \mathrm{ml}$ and MBC/MFC of 4.8 and $8.4 \mathrm{mg} / \mathrm{ml}$.

Conclusion: The results demonstrated the potential effects of selected plant extracts as a natural preservative that can protect wood from bacterial and fungal deterioration. The extracts can be applied to prevent furniture deterioration and raw wood protection.

\section{Background}

Globally preservative treated wood is a popular building material that release chemicals and results in environmental hazards. Growing environmental awareness and increasing demand for wood products, then the importance of fulfilling rising demand for these products on the one hand, and at the same reducing environmental impacts, is increasingly acknowledged. Microbial wood degradation is of great concern in wood industry. Wood is a complex material comprising of cellulose, hemicellulose and lignin as major components of cell wall, microbes consume this lignocellulose material and degrade wood (1). Bacterial-fungal association has been explored with respect to food and agriculture importance but little analyzed in context of wood degradation (2). Generally fungi are intended to be pioneers in microbial wood degradation but it was also reported that bacteria inhabit wood earlier than fungi (3). The coexistence of bacteria and fungi is responsible for wood degradation (4). Bacteria contribute with fungi in wood decay by degradation of lignocellulose material and by processing low molecule sugars and small aromatic compounds $(1,5,6)$. Soft-rot fungi (including Aspergillus) are the first among fungi to lay the substrate and followed by white and brown-rot fungi (7).

Hydrolytic enzymes are secreted by the hyphal tips of Aspergillus. These enzymes degrade lignocellulose into simple sugars that are absorbed by hyphae and consume organic matter ultimately by degrading wood $(8,9)$. Soft-rot fungi mainly degrade cellulose and hemicellulose but not degrade lignin efficiently(10-13). Lignin degradation by bacteria has been also amplified by Bacillus cereus (14, 15), Escherichia coli (16-18) and Pseudomonas aeruginosa (16, 17). Many Bacteria form biofilms on wood surface (14). Bacterial communities of $B$. cereus, $P$. aeruginosa form biofilm on wood surface and act as hazardous environmental pollutants (19) .

Bacteria are mostly independent of oxygen thus they intensively compete with fungi in wood degradation(20, 21). Mostly wood preservatives used now days are copper containing in origin, they are effective against fungal attack however bacterial colonies are resistant to copper containing wood preservatives(22). Chemicals like creosote, chromatid copper arsenate (CCA) and pentachlorophenol etc. are used as wood preservatives. These chemicals have environmental and health hazards as they release toxic metals like copper and arsenic. However these chemical preservatives are abstained 
to be used indoor. Thus there is growing need to develop alternative wood preservative chemicals for indoor use. Natural plant extracts and their phytochemicals as tannin are noteworthy alternatives for wood preservatives(23-25).

Phytochemicals such as tannins, flavonoids, terpenes and terpenoids have been active secondary metabolites and are considered as potent biocides against wood degrading microbes (26-28) Properties of medicinal plants have been preferably used worldwide due to their potential pharmacological activities, low cost and less toxicity as compared to synthetic drugs. Numerous plants and natural products have been reported for its antibacterial, antifungal and antiprotozoal effect. Properties of medicinal plants have been preferably used worldwide due to their prominent potential pharmacological activities, low cost and less toxicity as compared to synthetic drugs 2627 .

In this study ground powder of three plants i.e. Calotropis procera (leaves), Curcuma zedoaria (rhizome) and Swertia chirata (whole plant) was extracted with methanol, ethanol and chloroform. Parts of plants were selected due to its most reported phytochemicals Each plant extract was assayed against wood degrading bacteria $(B$. cereus, $P$. aeruginosa and E. coli) and soft-rot fungi (Aspergillus niger and Aspergillus flavus). For the first time the plant extracts which showed higher antimicrobial inhibition were subjected to in-vitro application by using Syzygium cumini wood and laminated veneer. The focus of study is to evaluate the effectiveness of plants extracts against wood decaying microbes.

\section{Methods}

\subsection{Collection of Plants}

S. chirata and C. procera were collected from different locations of Hafizabad City, Pakistan, during 2018. The rhizomes of $C$. zedoaria were purchased from market at Faisalabad city, Pakistan, in 2018. Leaves of $C$. procera, rhizomes of $C$. zedoaria and all parts of $S$. chirata were used. The plant material was washed with tap water, rinsed with distilled water and air dried under laboratory conditions. All the material was ground with electrical mill grinder and powders were stored in air tight jars separately for further use.

\subsection{Preparation of Plants Extracts}

About $150 \mathrm{~g}$ powder of leaves of $C$. procera, rhizomes of $C$. zedoaria and all parts of $S$. chirata for each extraction were weighed and extracted in Soxhlet apparatus with 75\% ethanol, methanol and chloroform solvents for 8-10 h. After extraction the solvents were evaporated by rotary evaporator at $60^{\circ} \mathrm{C}$. The extracts were oven dried at $30{ }^{\circ} \mathrm{C}$ for one week. Each extract was labeled and stored at $4{ }^{\circ} \mathrm{C}$ for future investigations.

\subsection{Phytochemical screening}

\section{Test for terpenoids}

Each sample in the amount of $0.5 \mathrm{mg}$ was dissolved with $1 \mathrm{ml}$ sulphuric acid $\left(\mathrm{H}_{2} \mathrm{SO}_{4}\right)$, chloroform (2 ml) and its concentrated form was depressed softly. The formations of red brown layer between other two layers will establish the presence of terpenoid (29).

\section{Test for coumarins}

Volume of $1 \mathrm{ml}$ of each extract and $1 \mathrm{ml}$ of $10 \%$ sodium hydroxide $(\mathrm{NaOH})$ were mixed together. The formation of yellow color indicate that the existance of coumarins.

\section{Test for flavonoids}

$4 \mathrm{ml}$ of plant extract was dissolved into $1.5 \mathrm{ml}$ of methanol solution then solution was warmed by adding magnesium metal. Concentrated solution of hydrochloric acid was added about 5-6 drops. Red color was observed that indicate the 
presence of flavonoids.

\section{Test for tannins}

$0.5 \mathrm{ml}$ of bark extract was dissolved in $1 \mathrm{ml}$ of distilled water added ferric chloride 2 drops into the solution. Greenishblack color was appeared that indicate the presence of tannins in the plant samples.

\section{Test for alkaloids}

To check alkaloids plant extract of $2 \mathrm{mg}$ and $1 \mathrm{ml}$ of concentrated $\mathrm{H}_{2} \mathrm{SO}_{4}$ were mixed by addition of Mayer's reagent. In the test tube white precipltate were developed or green colour also indicate the presence of alkaloids (30).

\section{Test for saponins}

$1 \mathrm{mg}$ of plant extract was suspended in $1 \mathrm{ml}$ of sanitized water and shaken for $15 \mathrm{~min}$. In the test tube $1 \mathrm{~cm}$ layer of foam appeared that indicated the presence of saponins.

\section{Detection of Glycosides:}

In $1 \mathrm{ml}$ of extract and few drops of Barrfoed's reagent were added and heated for two minutes in water bath. The red colored precipitates indicated the presence of glycosides.

\subsection{Isolation of Fungi and Bacteria}

The decayed wood samples were collected from Government College University, Faisalabad. The Aspergillus niger and Bacillus cereus were isolated from decayed wood of Syzygium cumin while Aspergillus flavus, Escherichia coli and Pseudomonas aeruginosa were isolated from decayed Laminated veneer. About $50 \mathrm{mg}$ of each sample was suspended in $1 \mathrm{ml}$ of distilled water and homogenized by vortex. Then 10 -fold serial dilution was performed and dilution $10^{-4}$ and $10^{-5}$ were spread in $100 \mu \mathrm{l}$ on nutrient agar plates for bacteria and Potato Dextrose Agar (PDA) plates supplemented with $1 \%$ Chloramphenicol for fungi. The plates for bacterial isolation were incubated for 24 hours at $37^{\circ} \mathrm{C}$ while for fungi plates were incubated for 7 days at $30-35^{\circ} \mathrm{C}$. By sub-culturing, isolated colonies were obtained and they were maintained in stock cultures for future investigations.

\subsection{Identification of Fungi and Bacteria}

The isolated microbes were identified from the Department of Microbiology at Government College University, Faisalabad with the cooperation of faculty.

\subsection{Antimicrobial Assay}

The antimicrobial activity was assayed by disc diffusion method. Nutrient agar plates for bacteria and PDA plates for fungi were prepared and incubated for $24 \mathrm{~h}$ and $72 \mathrm{~h}$ respectively. The plates were seeded with $100 \mu \mathrm{l}$ of bacterial culture $\left(1.5 \times 10^{7}\right)$ and fungal culture $\left(1.0 \times 10^{5}\right)$ then allowed for $15 \mathrm{~min}$ to settle. Sterilized cork borer was used to make wells. The wells were loaded with $50 \mu \mathrm{l}(50 \mathrm{mg} / \mathrm{ml}$ distilled water) of each extract and drug for each microbe, Gentamicin and Itraconazole were used as positive control for bacteria and fungi respectively. Plates were allowed to settle for 30 min and then incubated for $24 \mathrm{~h}$ for bacteria and $72 \mathrm{~h}$ for fungi. The size of zone of inhibition was measured by Vernier caliper. Each experiment was performed in triplicate. All extracts that showed maximum anti-microbial activity in disc diffusion assay were subjected to in-vitro application. Each of them was used to prevent wood degradation according to its respective biocidal activity against particular microbe.

\subsection{Determination of minimum inhibitory concentration (MIC) and Minimum bactericidal/fungicidal concentration (MBC/MFC)}


Plant extracts which showed higher antimicrobial activity were prepared separately by adding $300 \mathrm{mg}$ into $100 \mathrm{ml}$ of distilled water. For this stock different concentrations $(7.2,6.0,4.8,3.6,2.4,1.2 \mathrm{mg} / \mathrm{ml})$ were prepared in broth. $50 \mu \mathrm{l}$ inoculum was put into each concentration except control. All the concentrations now placed into incubator for $24 \mathrm{~h}$ for bacteria and $72 \mathrm{~h}$ for fungi at their respective temperatures. $50 \mu \mathrm{l}$ growth was added into control tubes before taking absorbance at $600 \mathrm{~nm}$. After that for MBC, subcultured the streaks taken from two lower concentation of MIC on plates, incubated for their respective time and temperature, and then examined the plate with no growth. All experiments were performed in triplicates.

\subsection{Wood blocks preparation}

Syzygium cumini wood and laminated veneer samples were provided by woodworking shop in Faisalabad city, Pakistan, July 2019. Wood blocks were prepared with $10 \times 10 \times 5 \mathrm{~mm}$ dimension, autoclaved and saved in sterilized bags.

\subsection{Antimicrobial activity of wood treated with extracts}

The wood samples were soaked in extracts $(50 \mathrm{mg} / 1 \mathrm{ml}$ distilled water) for $6 \mathrm{~h}$. After soaking they were placed on Nutrient agar and PDA plates seeded with $100 \mu \mathrm{l}$ of each microbial culture. Positive control wood samples were treated with distilled water. The plates were incubated for 3 days for bacteria and $7-10$ days for fungi at $30-35^{\circ} \mathrm{C}$. The inhibition zones were measured and recorded according to method described by (31).

\section{Statistical Analysis}

All experiments were performed in triplicate. The SPSS software version 22, 2013 was used for statistical analysis. The biocidal potential of plants (C. procera, S. chirata and C. zedoaria) was analyzed statistically with two-way analysis of variance (ANOVA) and Tukey's test for comparison. The results of inhibition zones against the growth of microbes by each solvent and positive control (Drug) were analyzed with one-way analysis of variance (ANOVA) and Tukey's test. In case of application, the potential of wood blocks treated with extracts to reduce bacterial and mycelial growth were evaluated with one-way analysis of variance (ANOVA) procedure. The means (Mean \pm Standard Deviation) were compared against the control treatment with $95 \%$ confidence interval at 0.05 -value.

\section{Results}

\subsection{Phytochemicals}

Physical appearance of extracts like color, odour and texture showed the difference in their quality. Results demonstrated that maximum secondary metabolites were found in order S. chirata > C. procera > C. zedoaria as shown in Table 1.

\subsection{Antibacterial activity of plants extracts}

All plants extracts showed antibacterial activity but varied against different strains of bacteria. The highest bactericidal potential was examined with ethanol extract of $S$. chairata against $E$. coli $(19.0 \mathrm{~mm})$. This extract exhibited bactericidal potential near to the Gentamicin antibiotic. No antibacterial activity with methanol extract of $S$. chirata and ethanol extract of $S$. chirata and $C$. zedoaria was observed against $P$. aeruginosa. The methanolic extract of all tested plants was more remarkable against all bacterial strains as represented in table 2 . Inhibition index of $C$. procera extracts was found more powerful against all bacterial strains with the exception of chloroform extract against $P$. aeruginosa. It was also observed ethanol and chloroform extract of $C$. zedaira fail to control growth of E.coli and $P$. aeruginosa respectively as shown in Fig. 1. The MIC and MBC of the most effective plant extracts were employed to evaluate their bacteriostatic and bactericidal properties. The MIC values ranged from 3.6 to $6.0 \mathrm{mg} / \mathrm{ml}$ for all the tested bacteria and MBC was found to be 6.2 to $7.2 \mathrm{mg} / \mathrm{ml}$ (Table 4$)$. 


\subsection{Anitifungal activity of plant extracts}

The antifungal activity of different extracts was also varied against different fungal strains. The ethanol extract of $S$. chirata and the methanol extract of $C$. procera exhibited stronger fungicidal potential against $A$. flavus $(19.33 \mathrm{~mm})$ and $A$. niger $(19.0 \mathrm{~mm})$ respectively as shown in table 3 . These extracts demonstrated fungicidal potential equal or more than Itraconazole. Extracts of $C$. zedaira did not show any antifungal activity against $A$. flavus and $A$. niger. Chloroform extract of $C$. procera and $S$. chirata was not able to inhibit the growth of $A$. niger. It was observed that $A$. flavus is more sensitive to all extracts of plants than $A$. niger. The results summarized in table-2 and table-3 depicted that the studied plant extracts exhibited bactericidal and fungicidal potential against tested microbes. Although chloroform extract of these plants showed poor activity but ethanol and methanol extracts were established to have strongest and immense action spectrum. The study revealed that $S$. chirata exhibited strongest and broadest biocidal spectrum of action followed by $C$. procera and $C$. zedaira respectively as shown in fig- 1 . The MIC of active extracts was estimated to be 4.8 to $6.0 \mathrm{mg} / \mathrm{ml}$ and MFC determination was in the range of 6.0 to $8.4 \mathrm{mg} / \mathrm{ml}$ (Table 4).

\subsection{Visual Observation}

The plant extracts that showed strongest bactericidal and fungicidal activities against particular microbes evaluated by disc diffusion method were applied for application as promising natural extracts to save wood degradation. Antimicrobial effects of plant extracts applied to the laminated veneer and $S$. cumini wood against selected microorganisms were assessed and compared with the control (untreated). The visual observations of the growth have been demonstrated in Fig. 2. Application of selected plants extracts to wood samples against tested microbes exhibited noteworthy results.

\subsubsection{Antibacterial activity of woods treated with Plants extracts}

Laminated veneer treated with ethanol extract of $S$. chirata showed strongest bactericidal potential against $E$. coli $(82.67 \mathrm{~mm})$ followed by ethanol extract of $C$. zedoaria against $P$. aeruginosa $(71.0 \mathrm{~mm})$ and methanol extract of $S$. chirata against $B$. cereus $(63.0 \mathrm{~mm})$. On the other hand $S$. cumini wood treated with ethanol extract of $C$. zedoaria exhibited high antibacterial activity against $P$. aeruginosa $(58.00 \mathrm{~mm})$ followed by the $S$. cumini treated with ethanol and methanol extract of $S$. chirata against E.coli $(53.33 \mathrm{~mm})$ and $B$. cereus $(43.33 \mathrm{~mm})$ respectively. The results showed that laminated veneer treated with selected extracts showed broadest spectrum of bactericidal activity than $S$. cumini as shown in Fig. 2.

\subsubsection{Antifungal activity of wood treated with plants extracts}

The antifungal activity of laminated veneer and S. cumini is illustrated in Fig. 2. The results described that laminated veneer treated with ethanol extract of $S$. chirata possess greatest fungicidal potential against $A$. flavus (92.00 mm) followed by laminated veneer treated with methanol extract of $C$. procera against $A$. niger $(65.66 \mathrm{~mm})$, whereas $S$. cumini wood exhibited high fungicidal potential when treated with methanol extract of $C$. procea against $A$. niger (40.33 mm) followed by the wood $S$. cumini treated with ethanol extract of $S$. chirata against $A$. flavus (32.67 mm).

\section{Discussion}

The antibacterial activity of plant extracts was investigated against wood degrading microbes including one strain of Gram positive bacteria $B$. cereus $(14,15)$ two strains of Gram negative bacteria E.coli $(15-18)$ and $P$. aeruginosa $(16,17)$. Paudel and Qin (32) also reported the isolation of E. coli, Bacillus sp. and Pseudomonas sp. from decaying wood samples. Kumar, Pandey (33) regarded A. niger, E. coli and B. cereus as wood degrading microbes.

The study revealed that by using well diffusion method all selected plants exhibited antimicrobial activity but different solvents varied in antimicrobial activity against tested wood degrading microbes. Among plants $S$. chirata was evaluated to possess strongest biocidal potential followed by $C$. procera then $C$. zedoaria. In case of $S$. chirata, methanol extract 
showed prominent bactericidal potential against $B$. cereus although ethanolic extract of $S$. chirata exhibited extensive bactericidal and fungicidal action against E.coli, P. aeruginosa and wood soft-rot fungus $A$. flavus. Phoboo, Pinto (34) reported that the ethanolic extract of $S$. chirata possess mangiferin, amarogentin and swertiamarin as active phytochemicals that are responsible for antimicrobial activity. Wazir (35) also amplified the antibacterial activity of methanolic exract of $S$. chirata. Our findings are also close to the results of Sekar (36) study that Mangefrin derived from $S$. chirata exhibited antibacterial activity against $E$. coli, $B$. cereus and $P$. aeruginosa and antifungal activity against $A$. flavus. The bactericidal potential of ethanol extract was also mentioned by Rehman, Latif (37) against $E$. coli and $P$. aeruginosa. BEHERA, BARIK (38) also revealed the antibacterial activity of $S$. chirata against gram positive and gram negative bacteria and E.coli was particularly mentioned. The phytochemical screening of $S$. chirata depicted the presence of terpenoids, coumarins, flavonioids, tannins, glucosides and alkaloids as active secondary metabolites. The results of phytochemical screening are in accordance to results of Khanal, Shakya (39). C. procera also showed antimicrobial activity against all tested microbes but its methanol and chloroform extract exhibited stronger fungicidal potential against wood soft-rot fungi $A$. niger (40) and $A$. flavus (41) respectively, while only methanol extract was evaluated to possess high bactericidal potential only against E.coli (42), it was reported by Agoramoorthy, Chandrasekaran (43) that $C$. procera possessed strongest fungicidal potential but less bactericidal potential. The study was also supported by suggestions of Yesmin, Uddin (44) and Waheed, Jabeen (40) that the leaves of $C$. procera exhibited good antimicrobial potential. Our result that methanol extract of $C$. procera exhibited broad spectrum of antimicrobial activity is the close in agreement with KAR, PATTNAIK (45) and SRangaiah, Lakshmi (46). The phytochemical screening exhibited the presence of terpenoids, tannins, flavonoids, and alkaloids and glycosides as active secondary metabolites, their presence was also reported by Akbani, Chavan (26), Tabassum, Ali (47). Thus these secondary metabolites are responsible for antimicrobial potential of $C$. procera (48).

C. zedaira was assessed to exhibit only bactericidal potential but no antifungal activity observed by its extracts. The study is supported by the results of Wilson, Abraham (49) that methanol, ethanol and chloroform extracts of $C$. zedoaria exhibited stronger antibacterial potential as compared to its activity against fungi. Ethanol extract of $C$. zedoaria exhibited strongest bactericidal activity against $P$. aeruginosa and $B$. cereus. Islam, Hoshen (50) examined the antibacterial activity of ethanol extract of $C$. zedoaria against $P$. aeruginosa and $B$. cereus and the study concluded the plausible application of this extract to control infections by these bacteria ( $P$. aeruginosa and $B$. cereus). The ethanol extract of $C$. zedoaria possess antimicrobial activity due to the presence of flavonoids and glycosides as active secondary metabolites as phytochemical screening revealed by Chachad, Talpade (27). The ethanol extract of $S$. chirata, methanol and chloroform extract of $C$. procera and ethanol extract of $C$. zedaira showed biocidal potential equal to antimicrobial drugs used as positive control against particular tested microbes. The statistical analysis showed that the means of control and these extracts are non-significant at p-value 0.05 shown in table 4 . Thus these plants extracts can be used as alternative to the drugs applied to cease the growth wood degrading microbes. The phytochemical screening showed that they have flavonoids, terpenoids, alkaloids and tannins that are responsible for exhibiting biocidal potential. The results of MIC and $\mathrm{MBC}$ of the effective plant extracts suggested that ethanol extracts of $S$. chirata and $C$. zedaira as well as methanol extracts of $S$. chirata and $C$. procera can be used to control and prevent wood deterioration. A great variation in MIC of all extracts demonstrated in several investigations may be due to considerable variation in their method of extraction, constituents as well as microbial strains used. Also, variation in MIC of different plant extracts may arise from variation in their chemical constituents and volatile nature of their constituents. These results are in accordance with the results of Islam et al. ${ }^{50}$.

The plants extract that showed broadest spectrum of bactericidal and fungicidal action was applied to treat $S$. cumini wood and laminated veneer lumber soaked with extracts. However $S$. cumini wood showed relatively mild response to bactericidal and fungicidal potential of extracts against wood degrading microbes as compare to laminated veneer. The reason is that laminated veneer is manufactured in compact form, polished and adhesives have been added. But the study showed that these extracts can be used as alternative of chemical adhesives which are used in manufacturing of 
laminated veneer. As natural products are inexpensive, thus their use for veneer adhesives, lamination of veneers and polishing of crude wood can save wood industry expenditures for importing wood preservative chemicals and crude wood preservative materials. It has been reported that copper in wood preservatives does not inhibit bacterial growth on wood; it only inhibits fungal growth (22). In fact commonly wood preservatives are antifungal they do not have bactericidal potential but bacteria also degrade wood by consuming lignin. Aviat, Gerhards (51) reported that microbes associated with wooden utensils are the major cause of food poisoning. However treatment of wooden utensils with chemicals is health hazardous thus the use of natural preservative may sort out this issue. The studied plant extracts have both fungicidal and bactericidal potential, in application their use as natural wood preservative may enhance the durability of S. cumini and laminated veneer wood, and of course other wood samples too. It has been reported that tannins and phenolic compounds are used to make wood adhesives (52). Thus it was evaluated that above selected plant extracts exhibited biocidal potential against wood degrading microbes so, reported extracts can be exploited as potential safe wood preserving agent and a better alternative to chemical preservatives.

\section{Conclusions}

The phytochemical analysis of tested plant extracts showed the presence of a wide spectrum of secondary metabolites that are responsible for inhibition of microbial growth and prevention of wood degradation. The linear growth of all microbes was significantly affected $(p<0.05)$ by the types of plants and solvents of extracts. It is concluded that $S$. chirata exhibited strongest and broadest biocidal spectrum of action followed by $C$. procera and $C$. zedoaira. The ethanol and methanol extract of $S$. chirata, methanol extract of $C$. procera and ethanol extract of $C$. zedoaria can be utilized as alternative wood. In general these extracts could be useful tools for protection of wood against microbe as alternative to chemical preservatives to save environment.

\section{Declarations}

Ethical approval: Not applicable

\section{Consent for publication:}

All authors have approved this paper for publication

\section{Availability of data and material:}

The datasets used and/or analyzed during the current study available from the corresponding author on reasonable request.

\section{Competing interest:}

The authors declare that they have no competing interests

\section{Funding:}

Research is supported by Government College University Faisalabad

\section{Acknowledgement:}

The authors are thankful to Department of Zoology, Government College University, Faisalabad for providing financial support for the research work.

\section{Authors' contribution}


JF conceived and designed the study. IA carried out the experiments. MSS performed data analysis. AAS wrote up the manuscript. YT edited the manuscript. WM identified the fungi AM made figures. All authors have read and agreed to the published version of the manuscript. All authors read and approved the final manuscript.

\section{References}

1. Noll M, Jirjis R. Microbial communities in large-scale wood piles and their effects on wood quality and the environment. Applied microbiology and biotechnology. 2012;95(3):551-63.

2. Frey-Klett P, Burlinson P, Deveau A, Barret M, Tarkka M, Sarniguet A. Bacterial-fungal interactions: hyphens between agricultural, clinical, environmental, and food microbiologists. Microbiol Mol Biol Rev. 2011;75(4):583-609.

3. Johnston SR, Boddy L, Weightman AJ. Bacteria in decomposing wood and their interactions with wood-decay fungi. FEMS microbiology ecology. 2016;92(11).

4. Boddy L. Interspecific combative interactions between wood-decaying basidiomycetes. FEMS microbiology ecology. 2000;31(3):185-94.

5. Brown ME, Chang MC. Exploring bacterial lignin degradation. Current opinion in chemical biology. 2014;19:1-7.

6. Valášková V, De Boer W, Gunnewiek PJK, Pospíšek M, Baldrian P. Phylogenetic composition and properties of bacteria coexisting with the fungus Hypholoma fasciculare in decaying wood. The ISME journal. 2009;3(10):1218-21.

7. Gobakken LR, Westin M. Surface mould growth on five modified wood substrates coated with three different coating systems when exposed outdoors. International Biodeterioration \& Biodegradation. 2008;62(4):397-402.

8. Bari E, Taghiyari HR, Naji HR, Schmidt O, Ohno KM, Clausen CA, et al. Assessing the destructive behaviors of two white-rot fungi on beech wood. International Biodeterioration \& Biodegradation. 2016;114:129-40.

9. Yang Y, Zhou J, Lu H, Yuan Y, Zhao L. Isolation and characterization of a fungus Aspergillus sp. strain F-3 capable of degrading alkali lignin. Biodegradation. 2011;22(5):1017-27.

10. Asina F, Brzonova I, Voeller K, Kozliak E, Kubátová A, Yao B, et al. Biodegradation of lignin by fungi, bacteria and laccases. Bioresource technology. 2016;220:414-24.

11. de Gonzalo G, Colpa DI, Habib MH, Fraaije MW. Bacterial enzymes involved in lignin degradation. Journal of Biotechnology. 2016;236:110-9.

12. Hamed SAM. In-vitro studies on wood degradation in soil by soft-rot fungi: Aspergillus niger and Penicillium chrysogenum. International Biodeterioration \& Biodegradation. 2013;78:98-102.

13. Chang Y-C, Choi D, Takamizawa K, Kikuchi S. Isolation of Bacillus sp. strains capable of decomposing alkali lignin and their application in combination with lactic acid bacteria for enhancing cellulase performance. Bioresource technology. 2014;152:429-36.

14. Cennamo P, Lumaga MRB, Ciniglia C, Soppelsa O, Moretti A. Heterotrophic components of biofilms on wood artefacts. Journal of Wood Science. 2018;64(4):417-26.

15. Revol-Junelles A-M, Miguindou-Mabiala R, Roger-Maigne D, Milliere J-B. Behavior of Escherichia coli cells and Bacillus cereus spores on poplar wood crates by impedance measurements. Journal of food protection. 2005;68(1):80-4.

16. Munir MT, Aviat F, Pailhories H, Eveillard M, Irle M, Federighi M, et al. Direct screening method to assess antimicrobial behavior of untreated wood. European journal of wood and wood products. 2019;77(2):319-22.

17. Nosal E, Reinprecht L. PREPARATION AND APPLICATION OF SILVER AND ZINC OXIDE NANOPARTICLES IN WOOD INDUSTRY: THE REVIEW. Acta Facultatis Xylologiae Zvolen res Publica Slovaca. 2018;60(2):5-23.

18. Milling A, Kehr R, Wulf A, Smalla K. Survival of bacteria on wood and plastic particles: Dependence on wood species and environmental conditions. Holzforschung. 2005;59(1):72-81. 
19. Farber R, Dabush-Busheri I, Chaniel G, Rozenfeld S, Bormashenko E, Multanen V, et al. Biofilm grown on wood waste pretreated with cold low-pressure nitrogen plasma: Utilization for toluene remediation. International Biodeterioration \& Biodegradation. 2019;139:62-9.

20. Rinta-Kanto JM, Sinkko H, Rajala T, Al-Soud WA, Sørensen SJ, Tamminen MV, et al. Natural decay process affects the abundance and community structure of Bacteria and Archaea in Picea abies logs. FEMS microbiology ecology. 2016;92(7):fiw087.

21. Schellenberger S, Kolb S, Drake HL. Metabolic responses of novel cellulolytic and saccharolytic agricultural soil bacteria to oxygen. Environmental microbiology. 2010;12(4):845-61.

22. Lasota S, Stephan I, Horn MA, Otto W, Noll M. Copper in wood preservatives delayed wood decomposition and shifted soil fungal but not bacterial community composition. Appl Environ Microbiol. 2019;85(4):e02391-18.

23. Tascioglu C, Yalcin M, Sen S, Akcay C. Antifungal properties of some plant extracts used as wood preservatives. International Biodeterioration \& Biodegradation. 2013;85:23-8.

24. Harju AM, Venäläinen $M$, Anttonen $S$, Viitanen $H$, Kainulainen $P$, Saranpää $P$, et al. Chemical factors affecting the brown-rot decay resistance of Scots pine heartwood. Trees. 2003;17(3):263-8.

25. Dorado J, Van Beek T, Claassen F, Sierra-Alvarez R. Degradation of lipophilic wood extractive constituents in Pinus sylvestris by the white-rot fungi Bjerkandera sp. and Trametes versicolor. Wood science and technology. 2001;35(12):117-25.

26. Akbani A, Chavan S, Sharma A. TO STUDY PHYTOCHEMICAL AND ANTIMICROBIAL ACTIVITY OF CALOTROPIS PROCERA LEAF EXTRACTS. 2018.

27. Chachad D, Talpade M, Jagdale S. Antimicrobial Activity of Rhizomes of Curcuma zedoaria Rosc. Int J Sci Res (IJSR). 2016;5:938-40.

28. Windeisen E, Wegener G, Lesnino G, Schumacher P. Investigation of the correlation between extractives content and natural durability in 20 cultivated larch trees. Holz als Roh-und Werkstoff. 2002;60(5):373-4.

29. Saeed N, Khan MR, Shabbir M. Antioxidant activity, total phenolic and total flavonoid contents of whole plant extracts Torilis leptophylla L. BMC complementary and alternative medicine. 2012;12(1):221.

30. Damodaran A, Manohar S. Qualitative Screening for Phytochemicals of various solvents extracts of Cassia alata Linn. Leaves Herbal Tech Industry. 2012:11-3.

31. Behiry SI, Okla MK, Alamri SA, El-Hefny M, Salem MZ, Alaraidh IA, et al. Antifungal and antibacterial activities of Musa paradisiaca L. peel extract: HPLC analysis of phenolic and flavonoid contents. Processes. 2019;7(4):215.

32. Paudel YP, Qin W. Characterization of novel cellulase-producing bacteria isolated from rotting wood samples. Applied biochemistry and biotechnology. 2015;177(5):1186-98.

33. Kumar R, Pandey A, Varshney V. Antifungal Activity of the Essential Oil of Tagetes minuta Against Some Fungi of Forestry Importance. Journal of Biologically Active Products from Nature. 2019;9(1):67-72.

34. Phoboo S, Pinto MDS, Bhowmik PC, Jha PK, Shetty K. Quantification of major phytochemicals of Swertia chirayita, a medicinal plant from Nepal. Ecoprint: An International Journal of Ecology. 2010;17:59-68.

35. Wazir A. DETERMINATION OF CHEMICAL COMPOSITION AND BIOLOGICAL ACTIVITIES OF TERMINALIA BELERICA, SWERTIA CHIRATA AND ZANTHOXYLUM ARMATUM: University of Karachi.; 2017.

36. Sekar M. Molecules of Interest-Mangiferin-A Review. Annual research \& review in biology. 2015:307-20.

37. Rehman S, Latif A, Ahmad S, Khan A. In vitro antibacterial screening of Swertia chirayita Linn. against some gram negative pathogenic strains. Int J Pharm Res Dev. 2011;4:188-94.

38. BEHERA S, BARIK DP, NAIK SK. Antibacterial activity of some important medicinal plants. CURRENT SCIENCE. 2017;113(4):558. 
39. Khanal S, Shakya N, Thapa K, Pant DR. Phytochemical investigation of crude methanol extracts of different species of Swertia from Nepal. BMC research notes. 2015;8(1):821.

40. Waheed N, Jabeen K, Iqbal S, Javaid A. Biopesticidal activity of Calotropis procera L. against Macrophomina phaseolina. African Journal of Traditional, Complementary and Alternative Medicines. 2016;13(6):163-7.

41. Kareem S, Akpan I, Ojo O. Antimicrobial activities of Calotropis procera on selected pathogenic microorganisms. African journal of biomedical research. 2008;11(1).

42. Al-Snai A. Iraqi medicinal plants with antibacterial effect-A review. IOSR Journal of Pharmacy. 2019;9(8):22-103.

43. Agoramoorthy G, Chandrasekaran M, Venkatesalu V, Hsu M. Antibacterial and antifungal activities of fatty acid methyl esters of the blind-your-eye mangrove from India. Brazilian Journal of Microbiology. 2007;38(4):739-42.

44. Yesmin MN, Uddin SN, Mubassara S, Akond MA. Antioxidant and antibacterial activities of Calotropis procera Linn. American-Eurasian Journal of Agricultural \& Environmental Sciences. 2008;4(5):550-3.

45. KAR D, PATTNAIK PK, PATTNAIK B, KUANAR A. ANTIMICROBIAL ANALYSIS OF DIFFERENT PARTS EXTRACT IN DIFFERENT SOLVENT SYSTEM OF A WASTE WEED-CALOTROPIS PROCERA. Asian J Pharm Clin Res. 2018;11(2):227-30.

46. Rangaiah SG, Lakshmi P, Manjula E. Antimicrobial activity of seaweeds Gracillaria, Padina and Sargassum sps. on clinical and phytopathogens. Int J Chem Anal Sci. 2010;1(6):114-7.

47. Tabassum A, Ali A, Babar R, Mahboob T. Phytochemicals screening and free radical scavenging potential of leaf and flower extract of Calotropis procera. Journal of Pharmacognosy and Phytochemistry. 2016;5(5):47.

48. Ngemenya MN, Mbah JA, Tane P, Titanji VP. Antibacterial effects of some Cameroonian medicinal plants against common pathogenic bacteria. African Journal of Traditional, Complementary and Alternative Medicines. 2006;3(2):84-93.

49. Wilson B, Abraham G, Manju V, Mathew M, Vimala B, Sundaresan S, et al. Antimicrobial activity of Curcuma zedoaria and Curcuma malabarica tubers. Journal of Ethnopharmacology. 2005;99(1):147-51.

50. Islam M, Hoshen MA, Ayshasiddeka FI, Yeasmin T. Antimicrobial, membrane stabilizing and thrombolytic activities of ethanolic extract of Curcuma zedoaria Rosc. Rhizome. Journal of Pharmacognosy and Phytochemistry.

2017;6(5):38-41.

51. Aviat F, Gerhards C, Rodriguez-Jerez Jj, Michel V, Bayon IL, Ismail R, et al. Microbial safety of wood in contact with food: a review. Comprehensive reviews in food science and food safety. 2016;15(3):491-505.

52. Sandberg D. Additives in wood products-Today and future development. Environmental Impacts of Traditional and Innovative Forest-based Bioproducts: Springer; 2016. p. 105 - 72.

\section{Tables}

Table 1 Presence of phytochemicals in plant extracts 


\begin{tabular}{|c|c|c|c|c|c|c|c|c|c|}
\hline \multirow[t]{3}{*}{ Phytochemicals } & \multirow{2}{*}{\multicolumn{3}{|c|}{$\begin{array}{l}\text { Methanol } \\
\text { Extract }\end{array}$}} & \multirow{2}{*}{\multicolumn{3}{|c|}{$\begin{array}{l}\text { Ethanol } \\
\text { Extract }\end{array}$}} & \multirow{2}{*}{\multicolumn{3}{|c|}{$\begin{array}{l}\text { Chloroform } \\
\text { Extract }\end{array}$}} \\
\hline & & & & & & & & & \\
\hline & $\begin{array}{l}\text { C. } \\
\text { procers }\end{array}$ & $\begin{array}{l}\text { C. } \\
\text { zedoaria }\end{array}$ & $\begin{array}{l}\text { S. } \\
\text { chirata }\end{array}$ & C.procers & $\begin{array}{l}\text { C. } \\
\text { zedoaria }\end{array}$ & $\begin{array}{l}\text { S. } \\
\text { chirata }\end{array}$ & $\begin{array}{l}\text { C. } \\
\text { procers }\end{array}$ & $\begin{array}{l}\text { C. } \\
\text { zedoaria }\end{array}$ & $\begin{array}{l}\text { S. } \\
\text { chirata }\end{array}$ \\
\hline Terpenoides & + & - & + & + & - & +++ & - & - & + \\
\hline Coumarins & + & - & ++ & - & - & ++ & - & - & - \\
\hline Flavonoids & + & + & ++ & + & + & ++ & - & - & + \\
\hline Tannins & + & - & + & + & - & ++ & + & - & - \\
\hline Glycocides & - & + & + & + & + & + & - & + & + \\
\hline Alkaloides & ++ & - & ++ & + & - & ++ & + & - & + \\
\hline Saponins & + & - & + & - & + & + & - & - & - \\
\hline
\end{tabular}

Number of + shows intensity of presence of phytochemicals

Table-2 Comparison of each extract against bacteria

\begin{tabular}{|lllll|}
\hline Plants/Microbes & \multicolumn{4}{c|}{ Zone of inhibition of plant extracts (mm) } \\
\cline { 2 - 5 } & Gentamicin & Methanol & Ethanol & Chloroform \\
\hline C.procera & & & & \\
\hline P.aeruginosa & $15.00 \pm 1.00^{\mathrm{A}}$ & $7.33 \pm 1.15^{\mathrm{B}}$ & $7.66 \pm 2.08^{\mathrm{B}}$ & $0.00 \pm 0.00^{\mathrm{C}}$ \\
\hline E.coli & $16.33 \pm 1.52^{\mathrm{A}}$ & $15.00 \pm 1.00^{\mathrm{A}}$ & $10.00 \pm 2.00^{\mathrm{B}}$ & $9.66 \pm 1.52^{\mathrm{B}}$ \\
\hline B.cereus & $17.33 \pm 2.51^{\mathrm{A}}$ & $7.00 \pm 1.00^{\mathrm{B}}$ & $8.67 \pm 1.52^{\mathrm{B}}$ & $10.67 \pm 2.08^{\mathrm{B}}$ \\
\hline C. zedaira & & & & \\
\hline P.aeruginosa & $19.00 \pm 1.00^{\mathrm{A}}$ & $15.66 \pm 1.52^{\mathrm{B}}$ & $18.00 \pm 1.00^{\mathrm{AB}}$ & $0.00 \pm 0.00^{\mathrm{C}}$ \\
\hline E.coli & $21.00 \pm 1.00^{\mathrm{A}}$ & $7.66 \pm 1.52^{\mathrm{C}}$ & $0.00 \pm 0.00^{\mathrm{D}}$ & $13.66 \pm 2.51^{\mathrm{B}}$ \\
\hline B.cereus & $16.00 \pm 2.00^{\mathrm{A}}$ & $7.00 \pm 2.64^{\mathrm{B}}$ & $13.00 \pm 2.00^{\mathrm{AB}}$ & $11.66 \pm 4.72^{\mathrm{AB}}$ \\
\hline S.chairata & & & & \\
\hline P.aeruginosa & $17.00 \pm 1.00^{\mathrm{A}}$ & $0.00 \pm 0.00^{\mathrm{B}}$ & $0.00 \pm 0.00^{\mathrm{B}}$ & $14.33 \pm 2.08^{\mathrm{A}}$ \\
\hline E.coli & $16.33 \pm 0.57^{\mathrm{B}}$ & $16.33 \pm 0.57^{\mathrm{B}}$ & $19.00 \pm 1.00^{\mathrm{A}}$ & $14.33 \pm 0.57^{\mathrm{C}}$ \\
\hline B.cereus & $18.33 \pm 1.52^{\mathrm{A}}$ & $17.66 \pm 1.52^{\mathrm{A}}$ & $15.66 \pm 0.57^{\mathrm{AB}}$ & $13.66 \pm 1.52^{\mathrm{B}}$ \\
\hline
\end{tabular}

ANOVA (Mean \pm Standard Deviation); Tukey's Test; $\mathrm{P}<0.05$; Values (in rows) sharing same alphabets are insignificant and vice versa.

Table-3 Comparison of each extract against fungi 


\begin{tabular}{|lcccc|}
\hline Plants/Microbes & \multicolumn{4}{c|}{ Zone of inhibition of plant extracts (mm) } \\
\cline { 2 - 5 } & Itraconazole & Methanol & Ethanol & Chloroform \\
\hline C.procera & & & & \\
A.niger & $18.33 \pm 1.52^{\mathrm{A} \mathrm{B}}$ & $19.00 \pm 1.00^{\mathrm{A}}$ & $15.66 \pm 1.52^{\mathrm{B}}$ & $0.00 \pm 0.00^{\mathrm{C}}$ \\
\hline A.flavus & $15.33 \pm 1.52^{\mathrm{A}}$ & $13.33 \pm 2.08^{\mathrm{A}} \mathrm{B}$ & $8.00 \pm 2.00^{\mathrm{B}}$ & $14.66 \pm 2.51^{\mathrm{A}}$ \\
\hline C.zedaira & & & & \\
\hline A.niger & $15.00 \pm 1.00^{\mathrm{A}}$ & $0.00 \pm 0.00^{\mathrm{B}}$ & $0.00 \pm 0.00^{\mathrm{B}}$ & $0.00 \pm 0.00^{\mathrm{B}}$ \\
\hline A.flavus & $16.00 \pm 1.52^{\mathrm{A}}$ & $0.00 \pm 0.00^{\mathrm{B}}$ & $0.00 \pm 0.00^{\mathrm{B}}$ & $0.00 \pm 0.00^{\mathrm{B}}$ \\
\hline S.chairata & & & & \\
\hline A.niger & $15.66 \pm 1.15^{\mathrm{A}}$ & $9.33 \pm 2.08^{\mathrm{B}}$ & $6.66 \pm 1.15^{\mathrm{B}}$ & $0.00 \pm 0.00^{\mathrm{C}}$ \\
\hline A.flavus & $20.00 \pm 2.00^{\mathrm{A}}$ & $13.00 \pm 1.00^{\mathrm{B}}$ & $19.33 \pm 0.57^{\mathrm{A}}$ & $14.00 \pm 1.00^{\mathrm{B}}$ \\
\hline
\end{tabular}

ANOVA (Mean \pm Standard Deviation); Tukey's Test; $\mathrm{P}<0.05$; Values (in rows) sharing same alphabets are non-significant and vice versa.

Table-4 MIC, MBC/MFC of active plants extracts and growth inhibition of microbe with wood treated in active plants extracts

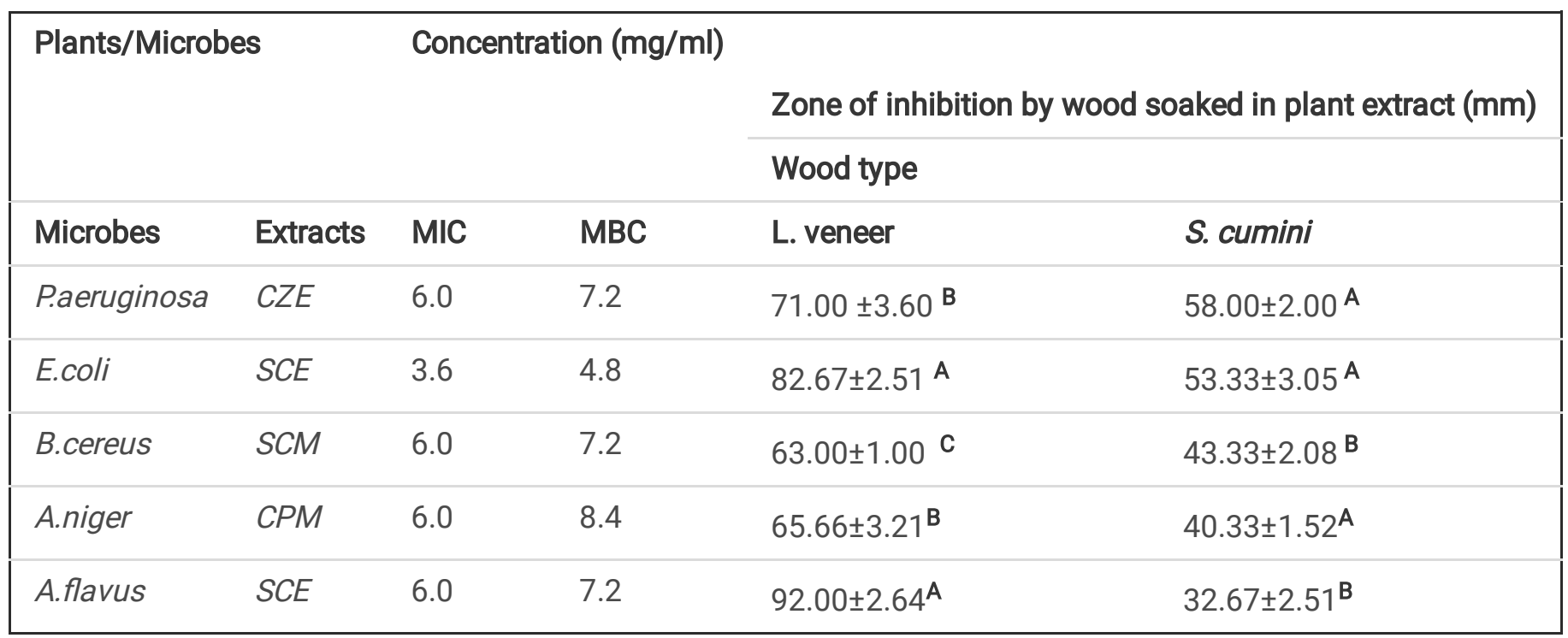

ANOVA (Mean \pm Standard Deviation); Tukey's Test; $\mathrm{P}<0.05$; Values (in rows) sharing same alphabets are non-significant and vice versa.

\section{Figures}




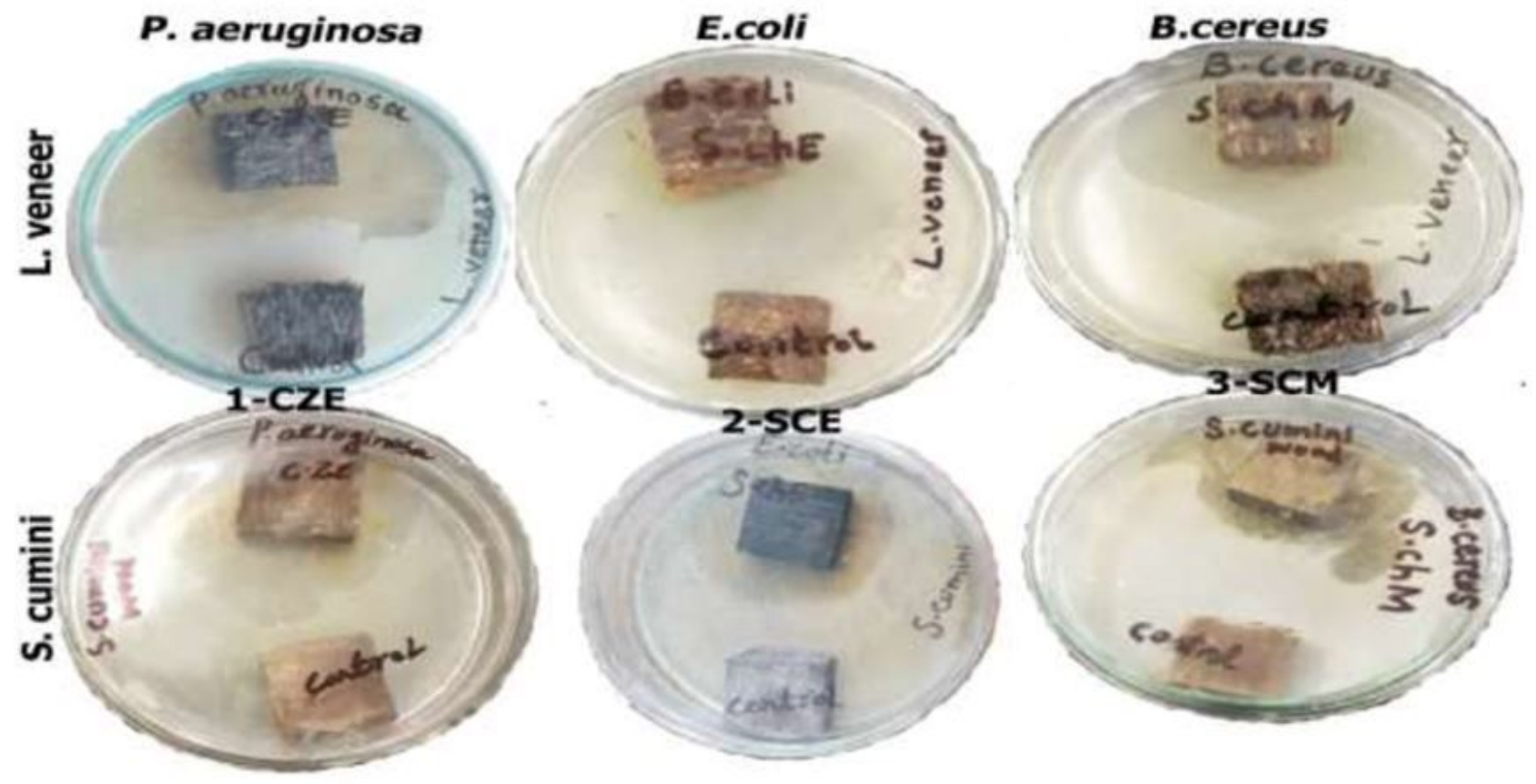

Figure 1

"See the Supplemental Files section for the complete figure caption".

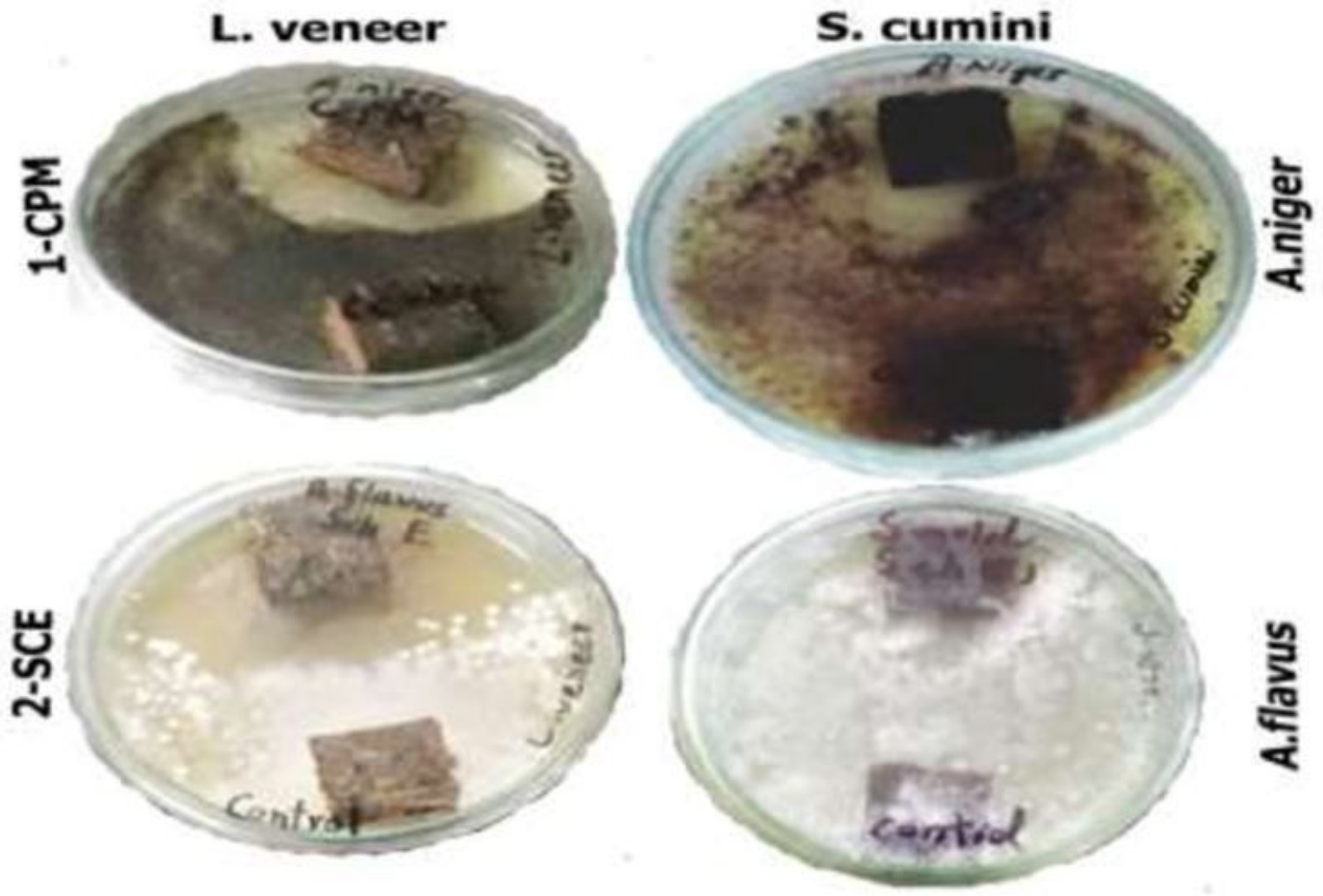

Figure 2

"See the Supplemental Files section for the complete figure caption". 


\section{Supplementary Files}

This is a list of supplementary files associated with this preprint. Click to download.

- FigureCaptions.jpg 